\title{
PEMUTAKHIRAN DATA PROFIL DAN POTENSI DESA BERBASIS DATA DASAR KELUARGA
}

\author{
Neneng Yani Yuningsih dan Iyep Saefulrahman
}

\author{
Program Studi Ilmu Pemerintahan, Fakultas Ilmu Sosial dan \\ Ilmu Politik Universitas Padjadjaran \\ email:nenengyany@gmail.com, sef73rahman@gmail.com
}

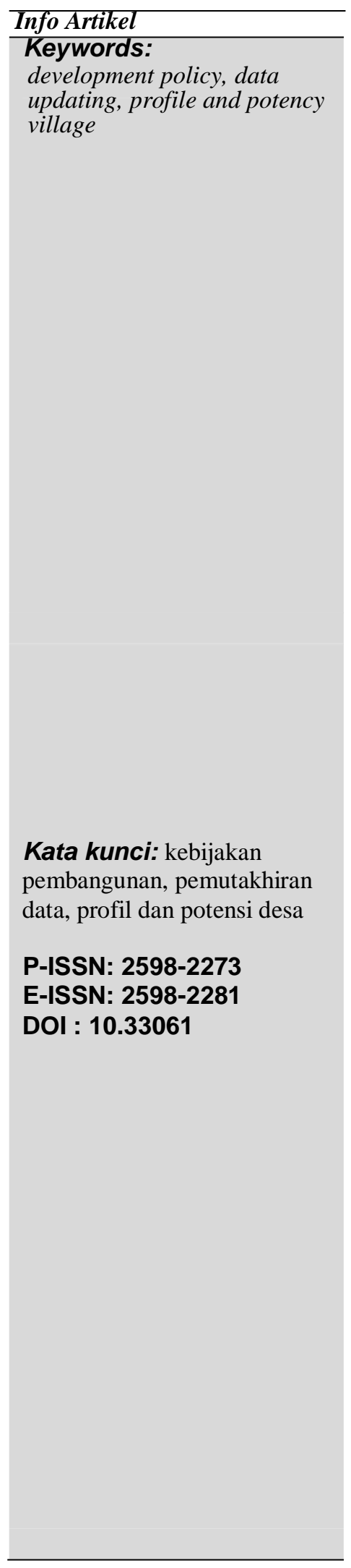

\begin{abstract}
In village development, the availability of accurate village profile data has an impact on its consistency policy direction. However, there are some problems that are encountered to be able to update it including the quality of human resources, finance and infrastructure. Therefore, Community Service Program (PKM) activity is intended to provide knowledge about the importance of updating data in planning village development and helping the government update profile data and potential of their villages. The method used is training in updating basic data based on family data which is carried out by providing material and its implementation in the field. Community Service Program can be carried out according to the planned schedule, especially in the provision of training materials. Meanwhile, implementation of material in the training could not be carried out because it was constrained because lack of information technology. However, in general the Community Service Program in Neglasari Village was going well, marked by an increasing participant knowledge and an acceleration of online data updating assisted by students who were doing Community Service Program. Indirectly, this achievement at the same time show that the obstacles faced by Neglasari Village were not only on its human resources but rather on aspects of financial support and infrastructure. The actual presence from the government is needed to support the updating of the profile and potential data of this village because it is not only the village institution that requires it, but rather the central and regional governments.
\end{abstract}

\section{Abstrak}

Dalam pembangunan, ketersediaan data profil desa yang akurat berdampak pada keajegan arah kebijakannya. Namun, ada beberapa masalah yang dihadapi untuk dapat memutakhirkannya di antaranya kualitas sumber daya manusia, keuangan serta prasarana dan sarana. Oleh karena itu kegiatan Pengabdian Kepada Masyarakat (PKM) ini ditujukan untuk memberikan pengetahuan tentang pentingnya pemutakhiran data dalam merencanakan pembangunan dan membantu pemerintah desa memutakhirkan data profil dan potensi desanya. Metode yang dipilih yaitu pelatihan pemutakhiran data berbasis data dasar keluarga yang dilakukan dengan pemberian materi dan pengaplikasiannya di lapangan. PKM dapat dilaksanakan sesuai dengan jadwal yang direncanakan, khususnya pada pemberian materi pelatihan. Sementara untuk pengaplikasian materi dalam pelatihan tidak dapat dilaksanakan karena terkendala oleh keharusan untuk menggunakan teknologi informasi. Walaupun begitu, secara umum PKM di Desa Neglasari berlangsung dengan baik yang ditandai dengan peningkatan pengetahuan peserta dan percepatan pemutakhiran data secara online yang dibantu mahasiswa yang sedang KKN. Secara tidak langsung, keberhasilan ini sekaligus menunjukan bahwa kendala yang dihadapi Desa Neglasari itu bukan pada sumber daya manusianya saja tetapi justru pada aspek dukungan dana serta sarana dan prasarananya. Diperlukan tindakan nyata dari pemerintah untuk mendukung pemutakhiran data profil dan potensi desa ini karena yang membutuhkan ketersediaannya bukan hanya pemerintah desa, tetapi justru pemerintah pusat dan daerah 


\section{PENDAHULUAN}

Fenomena di tataran empiris bahwa program-program pemerintah tidak membawa manfaat yang signifikan bagi masyarakat banyak dijumpai dihampir semua wilayah negara kita. Hal tersebut pada akhirnya menjalar pada kegiatan-kegiatan pemerintahan lainnya yaitu pembangun dan pemberdayaan yang seringkali salah sasasaran dan hasilnya tidak sesuai dengan yang dibutuhkan masyarakat. BPS mencatat Indeks Pembangunan Manusia (IPM) tahun 2018 memang membaik dibanding tahun sebelumnya dengan kenaikan sebesar $0,9 \%{ }^{1}$ Angka kemiskinan pun menurun hingga mencapai titik terendah sejak krisis moneter yaitu sebesar 9,82\%, jumlah penduduk miskin atau yang pengeluaran per kapita per bulan di bawah garis kemiskinan mencapai 25,95 juta orang ${ }^{2}$. Namun, tetap saja keberhasilan tersebut masih menyimpan permasalahan-permasalahan lain dalam bidang pembangunan dan pemberdayaan.

Kritik seringkali ditujukan pada para pelaksana kebijakan yang dianggap tidak memiliki kapasitas dan kredibilitas untuk dapat menyelenggarakan pemerintahan, pembangunan dan pemberdayaan, inefesien dalam pengelolaan keuangan dan lain-lain. Oleh karena itu banyak peneliti yang memokuskan penelitiannya pada upaya kondisi birokrasi pemerintahan Ginting dan Daeli (2012), Mildiana (2014), Indrayani (2015), Rahmad (2015), Yoman dkk (2016) yang merujuk perlunya peningkatan kapasitas birokrasi, khususnya di aras pemerintahan daerah. Pada konteks tata kelola pemerintahan di daerah, kepentingan pada peningkatan kualitas aparatur ini tidak terlepas dari kedudukan aparatur pemerintah sebagai salah satu faktor yang mempengaruhi pelaksanaan otonomi daerah (Kaho, 2010). Dalam hal ini dapat dikatakan bahwa aparatur pemerintah merupakan pelaku utama penyelenggaraan pemerintahan, pelayanan, pembangunan, dan pemberdayaan masyarakat.

Persoalan kualitas aparatur birokrasi pemerintah ternyata membawa dampak susulan yang semakin mempersulit ruang gerak pemerintah dalam mewujudkan tujuannya. Dampak dimaksud menyangkut ketersediaan data yang valid terkait kondisi dan potensi masyarakat yang ada dalam data profil desa. Data itu sangat penting, bagi pemerintah dalam merancang arah pembangunan nasionalnya. Sebagai suatu serangkaian usaha pertumbuhan dan perubahan yang berencana yang dilakukan secara sadar untuk mencapai kehidupan yang lebih baik dari sebelumnya dan mewujudkan kemandirian (Siagian, 1988), maka kebutuhan data yang valid dan mutakhir dalam pembangunan tidak dapat diabaikan. Strategi dan kebijakan pembangunan akan semakin terarah serta sesuai dengan kondisi dan kebutuhan masyarakat. Dalam hal ini, ketersediaan data yang valid akan memberi keakuratan perencanaan dan ketepatan arah kebijakan yang akan dirumuskan pemerintah sehingga dapat tepat sasaran.

Dalam sistem pembangunan nasional, pembangunan di aras desa memiliki kedudukan yang strategis. Hal ini disebabkan sampai saat ini basis pembangunan nasional tetap mengandalkan pembangunan desa. Fakta empiris menunjukkan bahwa wilayah negara kita terbagi ke dalam beribu-ribu desa (dalam Buku Indeks Pembangunan Desa Tahun 2014 jumlahnya sekitar 74.093 desa). Itu berarti (sekurangnya) potensi sumber daya alam dan sumber daya sosial tetap masih banyak terdapat di desa. Fakta ini juga yang menjadi pertimbangan dimasukkannya persoalan desa sebagai salah satu isyu strategis dalam RPJMN yaitu menyangkut pelaksanaan tatakelola pemerintahan desa yang masih dalam penyesuaian terhadap berlakunya UU No. 6 Tahun 2014 tentang Desa.

Berdasarkan undang-undang tersebut, Pemerintah diberikan amanat untuk mewujudkan kemandirian desa mengingat keberadaannya dan perkembangannya menjadi determinan bagi kemandirian bangsa dan negara kita. Dengan kata lain, pembangunan desa menjadi langkah awal pemerintah dalam membangun negara. Dari desalah awal negara dapat mengetahui permasalahan dan kebutuhan masyarakat. Oleh karena itu dibutuhkan data mengenai profil dan potensi desa yang akurat dan mutakhir. Dengan adanya data profil desa tersebut secara tidak langsung pemerintah dapat mengetahui gambaran kekuatan dan kemampuan dirinya. Bagi pemerintah desa sendiri menurut Susyani (2013), penelaahan terhadap potensi desa 
berguna dalam mengembangkan desa yang sesuai dengan karakteristik desa. Kesiapan dan keterbukaan masyarakat diperlukan untuk mendapatkan data yang akurat.

Kebutuhan akan data yang akurat dan mutakhir semakin nyata ketika pemerintah dalam hal ini Kementrian Desa, Daerah Tertinggal dan Transmigrasi memerlukan data untuk mengkaji dan mengevaluasi kebijakan Dana Desa. Pengkajian terutama terkait pada ada atau tidaknya perubahan pada kondisi desa sehingga berhasil merubah status desa pasca desa menerima bantuan dari Dana Desa. Secara tidak langsung, pengkajian terhadap data profil dan potensi desa ini dimaksudkan untuk melihat dampak Dana Desa pada pertumbuhan ekonomi dan kualitas hidup masyarakat. Hal ini terkait dengan manfaat data profil dan potensi desa itu sendiri yang akan mendata ketersediaan dan perkembangan potensi sarana dan prasarana sosial, ekonomi, budaya dan unsur lain.

Pada tataran empiris, secara umum kemutakhiran data kondisi dan potensi desa tersebut tidak dimililki oleh hampir semua desa, termasuk Desa Neglasari yang berada di wilayah Kecamatan Salawu Kabupaten Tasikmalaya, padahal kini untuk desa ditekankan adanya sistem informasi desa (SID) berbasis teknologi informasi. Hal tersebut dimaksudkan untuk menjawab kebutuhan dan tuntutan di era informasi yang menurut Davis seperti dikutip Kadir (2003) ketersediaan sistem informasi ini dapat membantu dalam pengambilan keputusan untuk saat ini dan mendatang.

Dari informasi awal diketahui data kondisi dan potensi desa yang ada dalam buku profil desa tidak menggambarkan kondisi dan potensi desa yang sesungguhnya. Pengisian profil desa seringkali berbasiskan data-data hasil perkiraan bukan hasil pemetaan dan pendataan secara partisiptif yang bebasiskan komunitas. Konsekuensinya sudah dapat dilihat ketika seringkali terjadi ketidaksesuaian data kemiskinan saat pelaksanaan berbagai program bantuan sosial dari pemerintah, walaupun andil pemerintah supra desa sendiri cukup besar terhadap permasalahan ini.

Kegiatan PKM ini dimaksudkan untuk memfasilitasi pemerintah desa (khususnya RT dan RW) dan masyarakat untuk mengidentifikasi potensi mereka, lingkungan tempat tinggalnya serta kebutuhan-kebutuhan dan masalah-masalah yang timbul dan dirasakan mengganggu kehidupan mereka, sehingga diketahui akar permasalahannya. Pemutakhiran profil dan potensi desa berbasis data dasar keluarga memberi kesempatan terbangunnya kedekatan antara pemerintah dengan warganya. Selain itu pada banyak kasus, seperti dijelaskan Soetomo (2006) kebutuhan yang dinyatakan belum tentu sesuai dengan yang dirasakan. Untuk dapat merasakannya sekurangnya harus terbangun kedekatan antara pemerintah dengan warganya. Oleh karena itu, pemutakhiran data profil dan potensi desa berbasis data dasar keluarga ini dapat juga dijadikan langkah awal yang strategis dalam mewujudkan harapan agar masyarakat lebih menjadi subjek dibanding subjek dalam pembangunan. Hal ini dimungkinkan karena dalam kegiatan pemutakhiran ini masyarakat secara langsung terlibat dan bersama pemerintah (RT) bersama-sama memetakan kondisi dan potensi mereka, lingkungan tempat tinggalnya, dan masyarakat secara keseluruhan

Sementara itu tujuannya untuk memberikan pelatihan untuk pemutakhiran data profil dan potensi desa kepada pemerintah desa (khususnya Ketua RT) dan masyarakat. Pilihan pada kegiatan ini dimaksudkan untuk mengatasi masalah dalam pengisian data profil dan potensi desa di antaranya kurangnya pemahaman aparat desa yang bertugas melaksanakan proses pencatatan data profil desa. Hal ini disebabkan belum adanya pelatihan atau bimbingan teknis untuk penyusunan dan pendayagunaan data profil desa.

Tujuan lainnya yaitu membantu Pemerintah Desa Neglasari dalam memutakhirkan data profil dan potensi desanya. Apalagi kegiatan pemutakhiran ini ternyata sejalan dengan program pemerintah yang secara rutin dilakukan tiga kali dalam 10 tahun. Terakhir kali pemutakhiran data profil dan potensi desa ini dilakukan tahun 2014. Oleh karena itu pada tahun 2017 Pemerintah pun kembali mencanangkan untuk melakukan pemutakhiran data. Namun ada beberapa kendala yang dihadapi oleh Pemerintah Desa Neglasari sehingga sampai dengan saat ini (2018) belum mampu melaksanakan pemutakhiran data profil dan potensi desanya secara keseluruhan. 
Kendala pertama terkait dengan sumber daya manusia yang terampil untuk melakukan pemutakhiran. Selain kesediaan untuk terjun langsung ke lapangan, pemutakhiran untuk sekarang dilakukan dengan berbasis elektronik. Artinya dituntut kemampuan dari petugas pemutakhiran dalam mengoperasikan komputer dan internet. Kendala Kedua terkait dengan pendanaanya. Dalam pemutakhiran data profil dan potensi desa ini langkah awalnya tetap melakukan pendataan secara manual dengan pengisian formulir yang terdiri dari 10 lembar untuk per KK nya. Jumlah KK di Desa Neglasari sebanyak 1.595 KK. Untuk memperbanyak formulir tersebut, Pemerintah Desa tidak memiliki dana. Belum lagi untuk biaya operasional atau insentif bagi petugas pemutakhiran. Dana Desa yang diturunkan Pemerintah ke desa tidak dialokasikan untuk menyelesaikan pemutakhiran data karena sampai dengan tahun 2018 ini alokasinya lebih difokuskan pada pembangunan infrastruktur. Begitu pun dengan bantuan lain yang diterima desa seperti Bantuan Propinsi (Banprop) dan Alokasi Dana Desa (ADD) tidak dapat dialokasikan untuk mendukung pemutakhiran.

\section{METODE KEGIATAN}

Berkaitan dengan maksud dan tujuan yang hendak dicapai melalui kegiatan PKM ini maka metode yang digunakan diarahkan pada pelatihan atau bimbingan teknis yang meliputi beberapa kegiatan, di antaranya:

a. Pelatihan/bimbingan teknis pemutakhiran data profil dan potensi desa dengan metode ceramah dan diskusi

b. Pengaplikasian materi-materi yang telah dipelajari

Metode pembelajaran yang digunakan dalam PKM ini yaitu pelatihan yang dilakukan melalui ceramah dan diskusi. Metode ini dimaksudkan sebagai pengantar dan stimulus bagi peserta sehingga termotivasi untuk mengikuti pelatihan serta mau dan mampu mengaplikasikan materi pelatihan dalam melaksanakan tugas-tugas yang melekat pada jabatannya. Sementara dengan praktek diharapkan para peserta mampu melatih keterampilannya dalam melakukan pemutakhiran data profil dan potensi desa berbasis komunitas. Kegiatan PKM ini dilakukan selama 5 hari untuk semua kegiatan dari mulai pelatihan, praktek, dan pengaplikasian di lapangan.

Adapun bahan yang digunakan untuk mendukung kegiatannya di antaranya LCD proyektor dan laptop, serta contoh formulir daftar isian data dasar keluarga untuk kegiatan ceramah. Sementara kertas plano, spidol warna, dan perekat untuk praktek. Adapun untuk pemutakhiran data propil dan potensi desa bahan yang digunakan formulir isian data dasar keluarga, pulpen dan alas untuk menulis, alat rekam, laptop serta modem internet.

Untuk mengetahui keberhasilan kegiatan PKM ini dilihat dari keterlibatan peserta yang didasarkan pada intensitas kehadirannya selama pelatihan. Selain itu antusiasnya juga menjadi bahan evaluasi yang dilihat dari keaktifannya bertanya saat pelatihan dan saat melaksanakan kegiatan praktek atas materi yang telah dipelajarinya. Hal lainnya dalam kegiatan evaluasi ini yaitu pendampingan ke beberapa wilayah ke-RT yang diidentifikasi kebutuhannya dan dimutakhirkan data-data kependudukannya untuk kepentingan pengisian data potensi desa.

\section{HASIL DAN PEMBAHASAN}

Kegiatan PKM ini secara keseluruhan dilakukan di Desa Neglasari. Dalam pelaksanaannya bekerjasama dengan pemerintah desa khususnya Operator Sistem Informasi Desa (SID) yang secara khusus bertanggung jawab dalam pelaksanaan pemutakhiran data. Namun begitu, bukan berarti operator ini menjadi satu-satunya orang yang melaksanakan semua tahapan dalam pemutakhiran karena tugas utamanya lebih kepada pengentrian data yang dikumpulkan dari kegiatan pendataan oleh petugas. Operator dalam kegiatan PKM ini menjadi koordinator dalam kegiatan pemutakhiran data profil dan potensi desa di lapangan atau saat kegiatan pengaplikasian materi yang diterima peserta dalam kegiatan pembelajarannya.

Dalam penyelenggaraan pemerintahan, termasuk di dalamnya pemutakhiran data profil dan potensi desa, manusia pelaksana yang baik menjadi faktor penting yang akan mempengaruhi keberhasilannya. Kaho (1991) menjelaskan yang dimaksud dengan manusia 
pelaksana yang baik tersebut salah satunya adalah aparat pemerintah. Makna baik merujuk pada adanya pengetahuan, keterampilan dan mentalitas. Untuk kepentingan pemutakhiran data profil dan potensi desa melalui pengisian data dasar keluarga, maka aparat yang memiliki pengetahuan, keterampilan dan mentalitas yang baik dibutuhkan. Oleh karena itu, pelatihan menjadi pilihan dalam kegiatan PKM. Kegiatan diawali dengan diskusi kelompok terarah untuk mengetahui pengetahuan dan wawasan peserta. Untuk selanjutnya ditetapkan materi ajar yang akan diberikan pada sesi pelatihan dengan metode ceramah dan diskusi.

Dari diskusi terarah tersebut dihasilkan beberapa pengetahuan tambahan yang diperlukan oleh peserta. Di antaranya menyangkut pentingnya pemutakhiran dan penyajian data profil dan potensi desa yang akurat untuk perencanaan pembangunan desa, kedudukan masyarakat dalam pembangunan, pengenalan format isian Pemutakhiran Data Desa yang terbaru, sistem informasi desa dan teknik-teknik pengkajian desa secara partisipatif dengan mengambil acuan pada metode dalam partisipatory rural apparaisal (PRA) dan juga simulasi untuk entry data pemutakhiran yang sekarang sudah terintegrasi dalam suatu sistem secara nasional dan berbasis internet (online). Oleh karena itu, dalam pemutakhiran data tersebut dibutuhkan sarana komputer atau laptop dan jaringan internet.

Penambahan materi terkait perlunya pemutakhiran dan penyajian data dimaksudkan agar perangkat desa memahami bahwa dalam perencanaan pembangunan itu ketersediaan data yang akurat dan mutakhir merupakan faktor yang sangat penting. Sebagai contoh untuk data kependudukan ketertibannya (mutakhir dan akurat) sangat bermanfaat tidak hanya untuk pemerintah terkait statistik kependudukan, tetapi juga untuk individu yang akan mendapatkan keabsahan dan kepastian status hukum; untuk pihak-pihak lain terkait kebutuhan informasi untuk pelauanan kesejahteraan sosial, bisnis, asuransi, perbankan dan lain-lain serta untuk mereka yang berminat memanfaatkan keberadaan data-data tersebut (Haryanto \& B Sugeng, 2001). Sementara materi kedudukan masyarakat dalam pembangunan, dimaksudkan untuk memberikan pengetahuan pada peserta bahwa sesungguhnya masyarakat itu tidak hanya sebagai objek dalam pembangunan, tetapi justru harus diperlakukan sebagai subjek. Kesadaran terhadap kedudukan masyarakat tersebut penting karena keterlibatan masyarakat secara "utuh" dalam pembangunan desa menjadi bantuan atau energi yang tidak terkira, khususnya motivasi untuk berpartisipasi pada tahap-tahap selanjutnya dalam pembangunan. Menurut Soetomo (2006), hal tersebut dapat muncul karena adanya rasa memiliki pada program-program pembangunan yang ditetapkan yang melahirkan rasa memiliki untuk juga bertanggung jawab juga dalam mewujudkannya.

Pada era informasi dan teknologi, pengenalan sistem informasi desa (SID) menjadi penegtahuan yang harus dimiliki oleh semua pihak khususnya pemerintah karena merekalah sebagai pihak yang memiliki tanggung jawab utama dalam menyediakan data dan informasi khususnya terkait profil dan potensi penduduk. Oleh karena itu dalam kegiatan PKM ini pun pengenalan SID dianggap penting, apalagi UU No. 6 Tahun 2014 tentang Desa juga mengamanatkan bahwa desa dan masyarakatnya berhak mendapatkan akses terhadap informasi.

Sebetulnya, PKM pemutakhiran data profil dan potensi desa dasar keluarga ini pernah dilakukan pada tahun 2017 lalu. Peserta yang dilibatkan baru sebatas perangkat desa saja karena kegiatan baru pada pengenalan (sosialisasi) SID dan perlunya pemutakhiran data profil dan potensi desa. Sosialisasi pemutakhiran data dasar keluaraga Namun begitu, upaya untuk pemutakhiran data profil dan potensi desa tetap dilakukan dengan melakukan pelatihan singkat pada beberapa kader PKK dan Posyandu di Kapunuhan Sukaratu. Ada 5 RT di Kapunuhan Sukaratu ini yaitu RT 14-19, dengan jumlah Kepala keluarga sebanyak 342 KK, dan data lapangan untuk pemutakhiran profil dan potensi desa sudah berhasil dikumpulkan.

Pengentrian data lapangan (daftar isian data dasar keluarga) untuk pemutakhiran profil dan potensi desa tersebut untuk sekarang harus dilakukan secara online. Ketentuan ini menjadi hal yang sangat sulit untuk dilakukan mengingat para kader yang mendata di lapangan tidak mampu mengoperasikan komputer. Selain itu, sarana dan prasarana untuk melakukan pemutakhiran seperti laptop atau komputer kurang mendukung. Di kantor desa ada 4 set komputer, 3 buah di ruang perangkat desa dan 1 buah di ruang sekretaris desa. Hanya saja 
semua komputer tersebut digunakan untuk penyelenggaraan pemerintahan dan pelayanan masyarakat. Satu kendala lainnya yaitu pengentrian harus tersambung dengan jaringan internet. Kantor desa sebetulnya memiliki instalisinya hanya saja kapitas data yang dimilikinya terbatas dengan kecepatan akses yang kurang mendukung. Instalasi internet ini pun tersedia bukan fasilitas dari kantor desa tetapi urunan perangkat desa. Gambaran kondisi yang dihadapi Pemerintah Desa Neglasari tersebut sesuai dengan pernyataan Kaho (2010) yang menyebutkan bahwa ketersediaan peralatan atau sarana dan prasarana yang baik merupakan faktor yang mempengaruhi penyelenggaraan pemerintahan.

Untuk mengatasi hal tersebut, pengentrian dilakukan di rumah operator dengan menggunakan fasilitas internet dari telepon genggam yang disambungkan ke laptop. Pengentrian satu formulir isian terkait data kependudukan ternyata membutuhkan waktu kurang lebih 30-45 menit. Namun begitu, catatan waktu tersebut dapat dicapai jika sinyal internetnya stabil. Pada kenyataannya, sinyal internet di lokasi tempat tinggal operator desa kurang stabil kecuali pada jam-jam tertentu seperti pukul 03.00 sampai dengan 06.00. Dengan jumlah daftar isian sebanyak $342 \mathrm{KK}$, maka dibutuhkan waktu untuk pengisian seluruhnya selama 10.260-15.390 menit atau 171-256,5 jam. Dengan segala keterbatasan yang dimiliki, maka pengentrian data baru dapat dilakukan untuk 1 ke RTan saja di tahun 2017.

Pada tahun 2018, kegiatan PKM dilakukan kembali melanjutkan kegiatan PKM tahun sebelumnya. Pelatihan atau bimbingan teknis dalam PKM kali ini dilakukan pada tanggal 19 Oktober 2018. Ketua RT mulai dilibatkan sebagai peserta, hanya saja dari sebanyak 8 orang yang diundang sebagai perwakilan dari 4 kedusunan yang ada di Desa Neglasari yang dapat hadir hanya 2 RT dari 2 kedusunan. Namun ketidakhadiran peserta lainnya tidak menghalangi pelatihan karena ada perangkat desa yang juga turut hadir dalam pelatihan. Selain melakukan sosialisasi kembali terkait pentingnya pemutakhiran data profil dan potensi desa, pada PKM kali ini pun diberikan materi tentang peran dan kedudukan masyarakat dalam pembangunan yang harus mulai diperlakukan sebagai subjek pembangunan tidak hanya objek semata. Materi lainnya terkait dengan pengenalan aplikasi sistem informasi desa dan daftar isian data dasar keluarga. Data dasar keluarga ini menjadi data dasar bagi pemutakhiran profil dan potensi desa.

Pelatihan pemutakhiran data profil dan potensi desa pada PKM ini berlangsung dalam suasana yang informal (santai tapi serius). Selain karena peserta yang dapat hadir hanya sekitar 10 orang, suasana pelatihan seperti itu dimaksudkan agar penerimaan materi dapat lebih efektif karena peserta tidak terbatasi oleh protokoler ketika ada hal-hal yang hendak ditanyakan atau didiskusikan. Menurut Bangun (2012) tempat dan suasana pelatihan dapat menentukan efektivitas suatu pelatihan.

Ketidakhadiran peserta undangan bukan karena tidak merespon kegiatan tetapi lebih kepada jadwal yang tidak sesuai dengan waktu longgar peserta yang juga memiliki kegiatan rutin (bekerja) dan yang lainnya karena kesehatannya terganggu. Materi disampaikan oleh dosen PKM khususnya mengenai pentingnya pemutakhiran data dan kedudukan masyarakat dalam pembangunan. Sementara untuk pengenalan aplikasi SID dan daftar isian data dasar keluarga disampaikan oleh operator desa (Bapak Utang Munawar).

Walau di sisi kehadiran peserta kurang lengkap, tetapi aktivitas pelatihan cukup dinamis karena diskusi berjalan dengan dua arah. Artinya peserta juga memiliki ruang untuk menyampaikan pendapatnya. Ketidakhadiran sebagian peserta pada akhirnya justru menjadikan pelatihan lebih kondusif karena suasana menjadi lebih tenang dan dapat fokus pada materi yang disampaikan. Kondisi ini menjadi pengalaman bagi PKM selanjutnya jika hendak melakukan pelatihan lebih baik dengan membaginya ke dalam kelas kecil. Jika pesertanya banyak dapat dilakukan beberapa kelas atau sesi. Kepesertaan ternyata berdampak pada efektivitas suatu pelatihan. Hal ini pun menjadi temuan Rustiana (2010) yang menyarankan agar dalam memilih peserta pelatihan agar dilakukan secara selektif karena dalam pelatihan diharapkan ada perubahan dalam perilaku para pesertanya.

Bersamaan dengan kegiatan PKM ini, ada kegiatan KKN mahasiswa dari Universitas Padjadjaran sebanyak 6 orang pada tanggal 26 Oktober 2018. Kehadiran mahasiswa KKN ini disambut oleh Pemerintah Desa khususnya operator desa karena diharapkan dapat membantu 
pengisian dan sekaligus pengentrian data dasar keluarga ke dalam profil desa secara online. Apalagi mahasiswa terbiasa menggunakan perangkat laptop yang terhubung dengan jaringan internet. Oleh karena itu mahasiswa pun dilibatkan dalam kegiatan pemutakhiran profil dan potensi desa. Kepada mahasiswa diberikan pelatihan singkat baik mengenai pentingnya pemutakhiran data maupun teknis pengisian daftar isian data dasar keluarga dan pengentriannya secara online.

Seperti telah dijelaskan, dalam pemutakhiran data profil dan potensi desa di Neglasari ini cukup banyak, tidak hanya sumber daya manusia dan sarana prasarana pendukung seperti komputer/laptop dan jaringan internet, sumber daya keuangan pun menjadi kendala yang menghambat pelaksanaan pemutakhiran data. Kaho (2010) menjelaskan bahwa keuangan merupakan salah satu faktor yang dapat mempengaruhi penyelenggaraan pemerintahan. Hal ini sangat dirasakan betul oleh Pemerintah Desa Neglasari saat hendak melaksanakan pemutakhiran data profil dan potensi desa, padahal ketersediaan data tersebut bukan hanya bermanfaat bagi pemerintah desa, tetapi bagi pemerintah daerah Kabupaten Tasikmalaya dan Propinsi Jawa Barat serta Pemerintah Pusat.

Untuk pemutakhiran tersebut, daftar isian (data dasar keluarga yang terdiri dari 12 lembar) harus digandakan untuk dapat menjaring dan mengumpulkan data di lapangan. Dengan jumlah KK sebanyak 1.595 maka dibutuhkan biaya penggandaan sebesar Rp. 4.785.000 dari perhitungan jumlah lembar daftar isian (12 lembar) dikali jumlah KK (1.595) dikali biaya photokopi Rp. 250/lembar. Biaya lain yang diperlukan yaitu untuk insentif petugas lapangan. Dengan asumsi Rp. 2.500/daftar isian, maka biaya yang dibutuhkan sebesar Rp. 3.987.500 yang dihasilkan dari perkalian jumlah KK dengan besaran insentif. Jumlah keseluruhan biaya untuk pengumpulan data lapangan adalah Rp.8.772.500,00.

Bagi Pemerintah Desa Neglasari, biaya sebesar itu tentunya sangat besar. Kalaupun ada, pilihannya mungkin untuk kegiatan lain yang secara langsung manfaatnya dapat dirasakan masyarakat. Oleh karena itu, kegiatan PKM berupa praktek lapangan (pengaplikasian hasil pelatihan) tidak dapat sesegera dilakukan karena menunggu ketersediaan sumber daya manusia, keuangan, serta sarana dan prasarananya. Dengan kata lain, pemutakhiran PKM berupa pengumpulan data lapangan dengan mengisi daftar data dasar keluarga, tidak dapat langsung dilakukan setelah pelatihan berupa penyampaian materi.

Kehadiran mahasiswa KKN pada akhirnya menjadi harapan dan jawaban atas permasalahan yang dihadapi Desa Neglasari. Mereka dapat membantu pemutakhiran data profil dan potensi desa, disela-sela jadwal mereka mengerjakan tugas KKNnya. Oleh karena itu, pengumpulan data lapangan dan pengentrian data dasar keluarga yang sudah dilakukan sebelumnya menunggu kehadiran kembali mahasiswa KKN tanggal 23-25 November 2018. Selama 3 hari tersebut, kegiatan dibagi ke dalam 2 sub kegiatan yaitu pengisian data dasar keluarga yang dilakukan di RT 20 RW 2 Dusun Naga pada tanggal 23 November 2018 mulai jam 07.00 sampai dengan 17.00. Aktivitas pengisian data dasar keluarga dapat dilihat pada gambar 1 berikut.
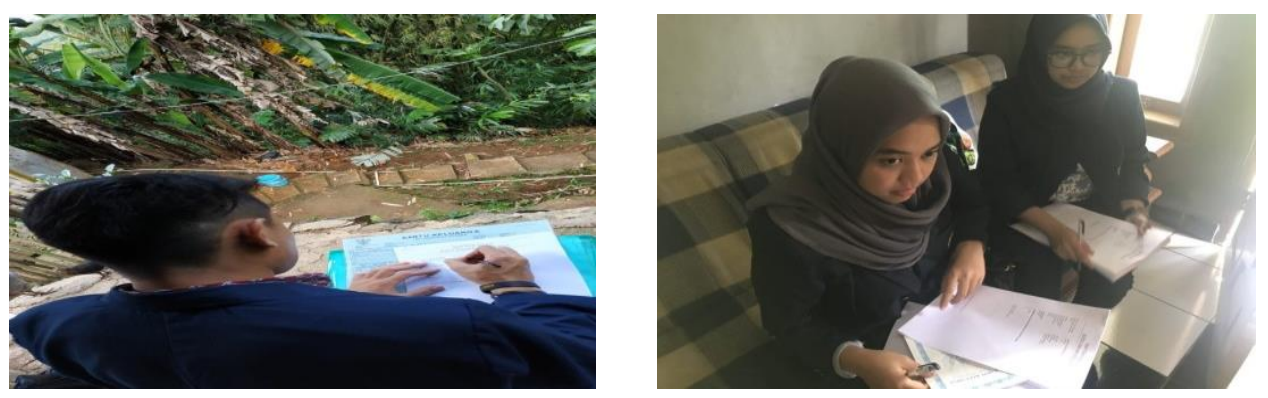

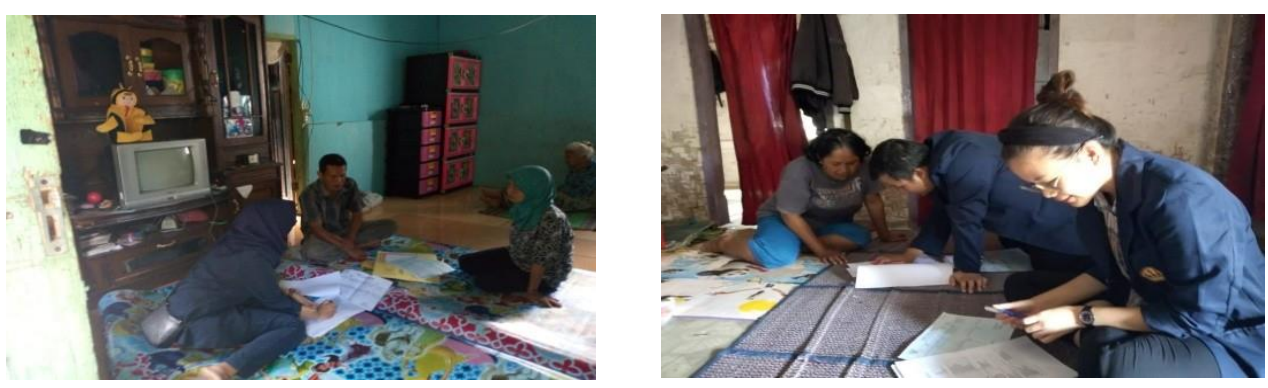

Gambar 1. Pengisian Data Dasar Keluarga di RT 20 RW 02 Dusun Naga

Pendataan keluarga dalam rangka pemutahiran profil desa ini tidak hanya kepala keluarganya saja, tetapi semua anggota keluarga yang tinggal di rumah tersebut. Di antaranya ada dalam satu rumah terdiri dari dua atau lebih keluarga. Selain ayah sebagai kepala keluarga, juga ada istri dan anak-anaknya serta cucu-cucunya. Oleh karena itu waktu pengisian tiap keluarga tidak akan sama, karena tergantung jumlah anggota dalam KK. Diperlukan waktu sekitar 30-45 menit untuk pengisian data dasar keluarga ini setiap keluarganya. Pada hari pertama, pendataan tidak dapat menyelesaikan semua KK yang ada di RT 20. Kondisi tersebut sebetulnya sudah diduga yang didasarkan pada estimasi waktu pengisian. Oleh karena itu dari 90 KK yang ada di RT 20, pengisian data baru dapat dilakukan pada 60 KK. Pengisian data dasar keluarga untuk sisanya sebanyak 30 KK dilakukan besoknya yaitu Hari Sabtu tanggal 24 Nopember 2018.

Tahap kedua dalam pemutakhiran adalah pengentrian data lapangan secara online. Sesuai dengan rencana awal, pengentrian dilakukan malam hari mulai pukul 20.00-23.00 dan dilanjutkan lagi pada pukul 06.30 oleh sebagian tim. Sebagian lagi kembali melakukan pengisian daftar data dasar keluarga pada keluarga lain yang belum dilakukan pendataan. Dalam pengentrian secara online ini tentu saja dibutuhkan sarana dan parasarana pendukungnya yaitu laptop dan jaringan internet. Ada sebanyak 6 laptop yang digunakan oleh mahasiswa KKN untuk pemutakhiran data profil dan potensi desa dengan jaringan internet melalui saluran (wifi) dari masing-masing handphonenya. Aktivitas pengentrian dapat dilihat pada gambar berikut.

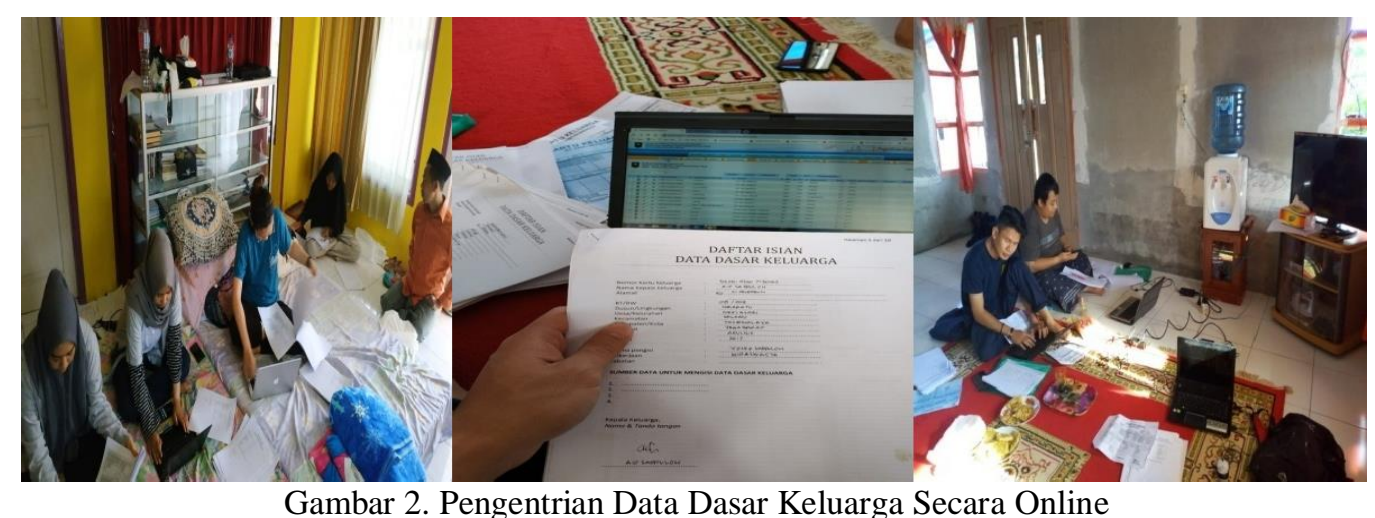

Data dasar keluarga yang dientri yaitu warga yang berada di RT 16, 18 dan 20. Seperti telah dijelaskan, dalam pengentrian ini dibutuhkan waktu sekitar 30-45 menit per daftar isiannya. Kecepatan pengisian ini tergantung pada keterampilan tim dalam mengoperasikan laptop dan kekuatan sinyal internet. Artinya faktor manusia dan sarana prasaran kembali menjadi faktor yang mempengaruhi efektivitas pengentrian data secara online. Hal ini sesuai dengan penjelasan Kaho (2010) terkait faktor-faktor yang mempengaruhi penyelenggaraan pemerintahan. Keberadaan mahasiswa KKN yang memiliki kemampuan dalam mengoperasikan laptop dan pengentrian secara online, memberikan kontribusi yang signifikan pada penyelesaian pemutakhiran data profil dan potensi desa. Ditambah dengan ketersediaan jaringan internet yang dimiliki oleh masing-masing mahasiswa, semakin mendukung pemutakhirannya. Hal ini dapat dilihat dari hasil yang dicapainya, hanya dalam waktu efektif satu setengah hari, sebanyak 90 KK di RT 20 sudah dapat dilakukan pengambilan data dasar 
keluarganya. Selain itu, dalam waktu satu hari dan satu malam, dapat dilakukan pengentrian terhadap 3 RT yang berarti sebanyak $262 \mathrm{KK}$ telah dimasukkan data dasar keluarganya secara online.

Kegiatan PKM dengan metode pelatihan atau bimbingan teknis dalam pemutakhiran data profil dan potensi desa ini pada aspek peningkatan pengetahuan sebetulnya sudah dapat dicapai. Hal ini dapat dilihat dari antusias peserta yang hadir saat sesi diskusi atau tanya jawab pada waktu pelatihan. Pada saat ke lapangan pun salah satu peserta yaitu ketua RT 20 turut berpartisipasi dengan menyiapkan semua keperluan khususnya telah memberikan informasi kepada warganya terkait pendataan keluarga oleh pemerintah desa. Pada saatnya pendataan, hanya dua keluarga saja yang tidak dapat diisi daftar dasar keluarganya karena kepala keluarganya tidak ada di tempat. Bersama operator desa, Ketua RT juga mendampingi mahasiswa saat melakukan pengisian daftar data dasar keluarga. Sesekali bertanya pada warga terkait informasi untuk keperluan pendataan. Hanya saja, pada saat pengentrian secara online tidak dapat mengikutinya karena tidak memiliki kemampuan mengoperasikan laptop dan pengentrian data secara online.

Dari pemaparan di atas korelasi antara kendala yang dihadapi dengan lambannya pemutakhiran data profil dan potensi desa di Desa Neglasari sangat jelas terlihat. Satu tahun setelah program pemutakhiran ini dicanangkan pemerintah, data profil dan potensi desa berbasis data dasar keluarga secara online hanya satu RT yang dapat dientrikan dan dimutakhirkan datanya. Percepatan pemutakhiran terlihat ketika ada bantuan tenaga terampil dengan dukungan sarana dan prasarananya (laptop dan jaringan internet). Hanya dalam jangka waktu 2 hari 2 malam, ada 1 RT yang dapat diambil data dasar keluarganya dan 3 RT yang data dasar keluarganya dapat dientri secara online sehingga sudah termutakhirkan datanya.

\section{KESIMPULAN}

Kegiatan Pengabdian Kepada Masyarakat di Desa Neglasari pada dasarnya sudah dapat dilaksanakan dengan baik. Hal ini dapat dilihat dari keberhasilan pelatihan dalam meningkatkan pengetahuan peserta terkait materi yang disampaikan. Selain itu, percepatan pemutakhiran data yang dilakukan dengan pengentrian data dasar keluarga secara online pun sudah dapat dilakukan. Keberhasilan ini sekaligus menunjukan bahwa kendala yang dihadapi Pemerintah Desa Neglasari dalam memutakhirkan data prosil dan potensi desanya nyata adanya. Namun begitu, kegiatan PKM ini tidak dapat membantu secara keseluruhan pemutakhiran data di Desa Neglasari karena persoalannya bukan pada sumber daya manusianya saja tetapi justru pada aspek dukungan dana (keuangan) serta sarana dan prasarananya. Oleh karena itu, pemerintah tidak dapat begitu saja meminta pemerintah desa memutakhirkan data profil dan potensinya tanpa ada dukungan secara nyata untuk melaksanakannya. Hal yang terjadi justru menjadi beban bagi perintah desa karena mau atau tidak dan mampu atau tidak, keputusan pemerintah harus dapat dilaksanakan oleh pemerintah desa sebagai bagian dari suatu daerah dan negara.

Kalau dikaji secara lebih dalam, sebetulnya kebutuhan akan data yang termutakhirkan bukan hanya pemerintah desa. Pemerintah pusat dan daerah pun pada dasarnya juga membutuhkan untuk merencanakan pembangunan di masing-masing arasnya. Jika dikaitkan dengan urgensitasnya, justru pemerintah supra desalah yang lebih membutuhkan data-data yang sudah termutakhirkan tersebut. Bagi pemerintah desa sendiri, kondisi dan potensi yang ada di wilayah kekuasaannya baik mengenai sumber daya alam, sumber daya manusia maupun sumber daya sosial dan ekonomi, sedikit atau banyak sudah diketahui. Kedekatan pemerintah desa dengan warganya yang juga merupakan warga suatu daerah dan negara (pusat), menjadi dasar atas kelebihan pengtahuannya dibanding pemerintah daerah dan pusat. Artinya, bagi pemerintah desa, data profil dan potensi desa berbasis data dasar keluarga dapat dengan mudah dimutakhirkan sepanjang ada kemauan dan kemampuan. Oleh karena itu, diperlukan political will dan good will dari pemerintah (pusat dan daerah) untuk secara nyata mendukung pemutakhiran data profil dan potensi di tiap desa. Pilihannya dapat secara langsung memberikan bantuan dana melalui program atau kebijakan pemutakhiran. Pilihan lainnya dengan memberikan arahan untuk mengalokasikan dana bantuan pada desa baik dari 
Dana Desa, Bantuan Propinsi, maupun ADD untuk keperluan pemutakhiran data profil dan potensi desa. Hal ini penting untuk dilakukan, mengingat kebutuhan atas data yang akurat tidak dapat dihindarkan. Dengan demikian pemutakhiran data tidak dapat menunggu satu atau lima tahun sekali agar data yang tersaji betul-betul akurat sehingga dapat bermanfaat.

\section{DAFTAR PUSTAKA}

Bangun, W. (2012). Manajemen Sumber Daya Manusia. Jakarta: Erlangga.

Ginting, Y., \& Daeli, S. P. (2012). Pengembangan Kapasitas Aparatur Pemerintahan Daerah di Era Otonomi (Studi Kasus: Pemerintah Daerah Kabupaten Samosir). Bina Praja, 105116.

Haryanto, R., \& B Sugeng. (2001). Pembangunan Administrasi Kependudukan Dalam Otonomi Daerah. Jurnal Sosiologi Indonesia(5).

Indrayani, T. D. (2015). Studi Tentang Pembangunan Sumberdaya Aparatur di Kantor Badan Perencanaan Pembangunan Daerah (Bappeda) Kota Samarinda. eJournal Ilmu Pemerintahan, 3(2), 989-1003.

KAdir, A. (2003). Pengenalan Sistem Informasi. Yogyakarta: Andi.

Kaho, J. R. (2010). Prospek Otonomi Daerah di Negara Republik Indonesia (Identifikasi Faktor-faktor yang Mempengaruhi Penyelenggaraan otonomi Daerah). Jakarta: Grafindo.

Mildiana, L. (2014). Kebijakan SDM Aparatur Ditinjau dari Perspektif Hubungan Kapasitas Aparatur dan Perwujudan Good Governance. Jejaring Administrasi Publik, VI(1), 450464.

Rahmad. (2015, Oktober). Peningkatan Kapasitas Aparatur Pemerintah Daerah Dalam Pelayanan Publik (Studi Pada Kantor Camat Peudada Kabupaten Bireun). $A L$ IJTIMA'I-International Journal Of Government and Social Science, 1(1), 13-18.

Rustiana, A. (2010). Efektivitas Pelatihan Bagi Peningkatan Kinerja Karyawan. Jurnal Dinamika Manajemen, 1(2), 137-143.

Siagian, S. P. (1988). Administrasi Pembangunan (cetakan ketiga belas). Jakarta: CV Haji Masagung.

Soetomo. (2006). Strategi-Strategi Pembangunan Masyarakat (cetakan kesatu). Yogyakarta: Pustaka Pelajar.

Susyanti, D. W. (2013). Potensi Desa Melalui Pariwisata Pedesaan. Jurnal Ekonomi dan Bisnis, 12(1), 33-36.

Yoman, M., Pratiknjo, M. H., \& Tasik, F. (2016). Kualitas Sumber Daya Aparatur Dalam Mencapai Tujuan Pembangunan di Distrik Yamo Kabupaten Puncak Jaya Propinsi Papua. Jurnal Administrasi Publik, 040(03). 